\title{
System Biology-A Computational Platform for Biological Research
}

\author{
Nida Tabassum Khan \\ Department of Biotechnology, Faculty of Life Sciences and Informatics, Balochistan University of Information \\ Technology Engineering and Management Sciences,(BUITEMS),Quetta, Pakistan
}

*Corresponding Author: Nida Tabassum Khan, Department of Biotechnology, Faculty of Life Sciences and Informatics, Balochistan University of Information Technology Engineering and Management Sciences,(BUITEMS),Ouetta, Pakistan

\begin{abstract}
System biology uses computational tools to assess and analyze how biological components interact with one another and it's surrounding in a precise manner displaying unique structural and functional characteristics to exhibit an appropriate response, contributing towards the stability of a specific biological system. Biological entities are dynamic and sophisticated.it is difficult to predict how these biological entities might behave when placed in a functional frame work. Therefore to investigate their systematic interacting properties, computational platform is utilized to describe and predict their dynamical behavior.
\end{abstract}

Keywords: HGP; Systems Biology Markup Language; Systems Biology Graphical Notation

\section{INTRODUCTION}

System biology is a subfield of bioinformatics which involves the use of mathematical and computational modelling to understand the dynamics of a biological system along with its interacting sub components for the precise representation of a functional biological system [1]. This discipline permits in silico interpretation of biological system by employing knowledge from different fields of science such as applied statistics, mathematics, informatics, engineering and life sciences. For example HGP (Human Genome Project) is one of the most significant contribution of this field [2, 3]. Employing mathematical and computational modeling approaches for data storage, for development of informatics tools for simulation, analysis and visualization of system units etc. Quantitative assessments of biological system is shaped in to valid mathematical models for the purpose of accurate analysis [4]. Therefore Systems Biology Markup Language (SBML) was designed for the development of computer-readable format for the representation of biological processes [5]. This computational language provides a unique format for addressing biological pathways using different tools that aids in exhibiting the biological framework with high reliability and accuracy [6, 7]. The graphical notation for the representation of biological processes has been proposed recently by Systems Biology Graphical Notation (SBGN) [8].As scientific research is increasing through the development of new technologies and instrumentation, biological databases such as primary and secondary have become an essential partner in such research for acquisition, management and analysis of biological information [9]. Such in silico analysis of biological system is crucial since increasingly biological research relies on information science and hence is managed by computational tools and databases. Therefore, these systems biology databases are crucial for quantitative modeling of biological systems [10].Mathematical depiction of the biological pathway depends on the knowledge of the system and the aim of the modeling process [11]. Figure 1 illustrates how system biology works. System biology approaches for modeling biological pathways could be achieved either by means of network-based analysis or mathematical modeling [12]. Network-based analyzing approaches uses graph theory to determine relation among biological entity (nodes) in the pathways. Such nodal networks appeared as directed or undirected graphs e.g. probabilistic graph model [13]. Mathematical modeling on the other hand transforms the reactions and entities into matrix form [14]. 


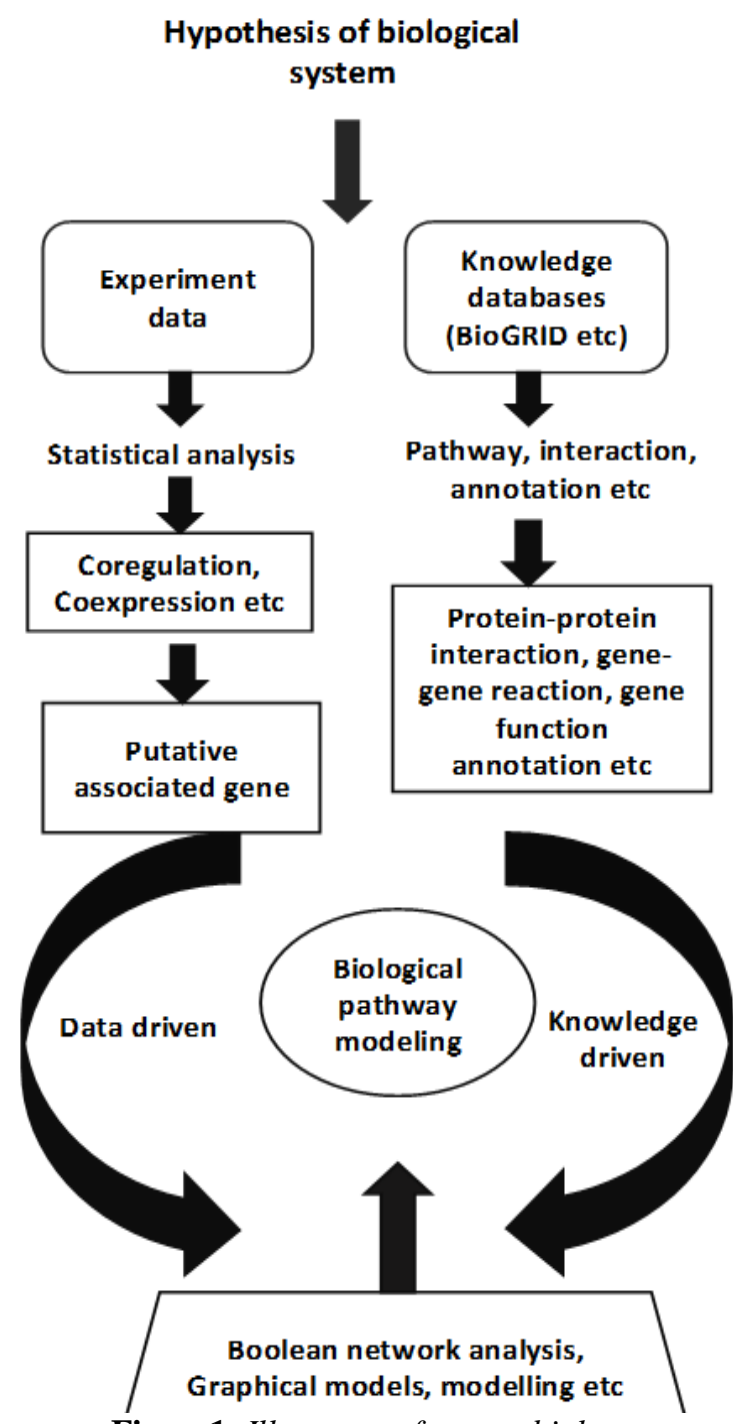

Figure1. Illustrates of system biology

Enlisted below is few system biology tools and database.

Table1. System biology tools and database

\begin{tabular}{|c|c|}
\hline Bioinformatics tools for system biology & Purpose \\
\hline BioFNet & Database for analysis and synthesis of biological systems [15] \\
\hline BioModels Database & $\begin{array}{l}\text { Warehouse of computational models of biological processes } \\
\text { [16]. }\end{array}$ \\
\hline BioSystems & $\begin{array}{l}\text { Database provides data on biological systems and their } \\
\text { component [17]. }\end{array}$ \\
\hline $\begin{array}{l}\text { ESCAPE Embryonic Stem Cells Atlas of } \\
\text { Pluripotency Evidence }\end{array}$ & $\begin{array}{l}\text { Integrates data based on mouse and human embryonic stem cells } \\
\text { from diverse high-throughput studies [18] }\end{array}$ \\
\hline Genome Proteome Search engine (GPSe) & Retrieve data from different biological databases [19] \\
\hline InnateDB & $\begin{array}{l}\text { Database providing information relating to signaling pathways } \\
\text { involved in the innate immune responses[20] }\end{array}$ \\
\hline IPAD & Database for Systematic Enrichment Analysis [21]. \\
\hline JWS Online Cellular Systems Modelling & $\begin{array}{l}\text { Provides access to a database of curated models of biological } \\
\text { systems [22] }\end{array}$ \\
\hline KBase & $\begin{array}{l}\text { Provides secure sharing of data, tools, and scientific conclusions } \\
\text { in predictive and systems biology [23]. }\end{array}$ \\
\hline MEMOSys & Database for Genome-scale metabolic models [24]. \\
\hline $\begin{array}{l}\text { PANTHER (Protein ANalysis Through } \\
\text { Evolutionary Relationships) }\end{array}$ & Classify proteins (and their genes) [25]. \\
\hline PhosphoPep 2.0 & $\begin{array}{l}\text { Provides interactive cross-examination of MS-derived } \\
\text { phosphorylation data from } 4 \text { different organisms [26]. }\end{array}$ \\
\hline
\end{tabular}




\begin{tabular}{|c|c|}
\hline $\begin{array}{l}\text { Plant Systems Biology Modelling } \\
\text { (PlaSMo) }\end{array}$ & $\begin{array}{l}\text { Permit scientists to share reviews, annotations and enhancements } \\
\text { of models [27]. }\end{array}$ \\
\hline PlateletWeb & For the analysis of platelet signaling [28]. \\
\hline $\begin{array}{l}\text { SABIO-RK Biochemical Reaction } \\
\text { Kinetics Database }\end{array}$ & $\begin{array}{l}\text { Database that contains data about biochemical reactions, their } \\
\text { kinetic rate etc [29]. }\end{array}$ \\
\hline SysMO-DB & $\begin{array}{l}\text { For determining, sharing and exchanging data, models and } \\
\text { processes in systems biology [30]. }\end{array}$ \\
\hline $\begin{array}{l}\text { Systems Biology and Medicine Database } \\
\text { (SBM DB) }\end{array}$ & Database of gene expression profiles [31]. \\
\hline Systems Biology Ontology (SBO) & Contain commonly used terms in Systems Biology [32]. \\
\hline SYSTOMONAS genome Database & $\begin{array}{l}\text { Store data related to metabolome, proteome and transcriptome } \\
\text { data and gene-regulatory networks [33]. }\end{array}$ \\
\hline $\begin{array}{l}\text { The Systems Biology Researcher } \\
\text { Database (SysBiolDB) }\end{array}$ & $\begin{array}{l}\text { Offers exchange of information worldwide for all systems } \\
\text { biology scientists [34] }\end{array}$ \\
\hline
\end{tabular}

\section{CONCLUSION}

Therefore system biology provides a computational approach for understanding the fundamentals of biological pathways using different modeling tools for simulation and visualization of biological processes on computational platform

\section{REFERENCES}

[1] Kitano, H. (2002). Computational systems biology. Nature, 420(6912), 206-210.

[2] Ireton, R. (2009). Computational systems biology. J. McDermott, R. Samudrala, R. Bumgarner, \& K. Montgomery (Eds.). Humana Press.

[3] Hood, L. (2003). Systems biology: integrating technology, biology, and computation. Mechanisms of ageing and development, 124(1), 9-16.

[4] Aderem, A. (2005). Systems biology: its practice and challenges. Cell, 121(4), 511-513.

[5] Hucka, M., Finney, A., Sauro, H. M., Bolouri, H., Doyle, J. C., Kitano, H., \& Cuellar, A. A. (2003). The systems biology markup language (SBML): a medium for representation and exchange of biochemical network models. Bioinformatics, 19(4), 524-531.

[6] Hucka, M., Finney, A., Sauro, H., \& Bolouri, H. (2003). Systems Biology Markup Language (SBML) Level 1: Structures and facilities for basic model definitions.

[7] Hucka, M., Finney, A. B. B. J., Bornstein, B. J., Keating, S. M., Shapiro, B. E., Matthews, J., ... \& Kitano, H. (2004). Evolving a lingua franca and associated software infrastructure for computational systems biology: the Systems Biology Markup Language (SBML) project. Systems biology, 1(1), 41-53.

[8] Le Novere, N., Hucka, M., Mi, H., Moodie, S., Schreiber, F., Sorokin, A., \& Bergman, F. T. (2009). The systems biology graphical notation. Nature biotechnology, 27(8), 735-741.

[9] Brazma, A., Krestyaninova, M., \& Sarkans, U. (2006). Standards for systems biology. Nature Reviews Genetics, 7(8), 593-605.

[10] Palsson, B., \& Palsson, B. Ø. (2015). Systems biology. Cambridge university press.

[11] Bruggeman, F. J., \& Westerhoff, H. V. (2007). The nature of systems biology. TRENDS in Microbiology, $15(1), 45-50$.

[12] Albert, R. (2007). Network inference, analysis, and modeling in systems biology. The Plant Cell Online, 19(11), 3327-3338.

[13] Bullmore, E., \& Sporns, O. (2009). Complex brain networks: graph theoretical analysis of structural and functional systems. Nature Reviews Neuroscience, 10(3), 186-198.

[14] Wang, R. S., Saadatpour, A., \& Albert, R. (2012). Boolean modeling in systems biology: an overview of methodology and applications. Physical biology, 9(5), 055001.

[15] Kurata, H., Maeda, K., Onaka, T., \& Takata, T. (2013). BioFNet: biological functional network database for analysis and synthesis of biological systems. Briefings in bioinformatics, 15(5), 699-709.

[16] Le Novere, N., Bornstein, B., Broicher, A., Courtot, M., Donizelli, M., Dharuri, H., \& Snoep, J. L. (2006). BioModels Database: a free, centralized database of curated, published, quantitative kinetic models of biochemical and cellular systems. Nucleic acids research, 34(suppl_1), D689-D691.

[17] Geer, L. Y., Marchler-Bauer, A., Geer, R. C., Han, L., He, J., He, S., \& Bryant, S. H. (2009). The NCBI biosystems database. Nucleic acids research, 38(suppl_1), D492-D496.

[18] Xu, H., Baroukh, C., Dannenfelser, R., Chen, E. Y., Tan, C. M., Kou, Y., \& Ma'ayan, A. (2013). ESCAPE: database for integrating high-content published data collected from human and mouse embryonic stem cells. Database, 2013. 
[19] Nehra, K., Nehra, V., Singh, B., Kumar, S., \& Kumar, M. (2018). Computer Simulation Using GPSC Package MATLAB, Simulink for Bioinformatics Professional. In ICT Based Innovations (pp. 251-262). Springer, Singapore.

[20] Lynn, D. J., Winsor, G. L., Chan, C., Richard, N., Laird, M. R., Barsky, A., \& Lo, R. (2008). InnateDB: facilitating systems- level analyses of the mammalian innate immune response. Molecular systems biology, 4(1), 218.

[21] Zhang, F., \& Drabier, R. (2012). IPAD: the integrated pathway analysis database for systematic enrichment analysis. BMC bioinformatics, 13(15), S7.

[22] Olivier, B. G., \& Snoep, J. L. (2004). Web-based kinetic modelling using JWS Online. Bioinformatics, 20(13), 2143-2144.

[23] Soh, C. K., Soh, A. K., \& Lai, K. Y. (1989). KBASE: A customizable tool for building DBase-compatible knowledge-based systems. Advances in Engineering Software (1978), 11(3), 136-148.

[24] Pabinger, S., Rader, R., Agren, R., Nielsen, J., \& Trajanoski, Z. (2011). MEMOSys: Bioinformatics platform for genome-scale metabolic models. BMC systems biology, 5(1), 20.

[25] Mi, H., Poudel, S., Muruganujan, A., Casagrande, J. T., \& Thomas, P. D. (2016). PANTHER version 10: expanded protein families and functions, and analysis tools. Nucleic acids research, 44(D1), D336-D342.

[26] Bodenmiller, B., Campbell, D., Gerrits, B., Lam, H., Jovanovic, M., Picotti, P., \& Aebersold, R. (2008). PhosphoPep - a database of protein phosphorylation sites in model organisms. Nature biotechnology, 26(12), 1339-1340.

[27] Kell, D. B. (2006). Systems biology, metabolic modelling and metabolomics in drug discovery and development. Drug discovery today, 11(23), 1085-1092.

[28] Boyanova, D., Nilla, S., Birschmann, I., Dandekar, T., \& Dittrich, M. (2012). PlateletWeb: a systems biologic analysis of signaling networks in human platelets. Blood, 119(3), e22-e34.

[29] Wittig, U., Kania, R., Golebiewski, M., Rey, M., Shi, L., Jong, L., \& Krebs, O. (2011). SABIO-RKdatabase for biochemical reaction kinetics. Nucleic acids research, 40(D1), D790-D796.

[30] Wolstencroft, K., Owen, S., Horridge, M., Krebs, O., Mueller, W., Snoep, J. L., \& Goble, C. (2011). RightField: embedding ontology annotation in spreadsheets. Bioinformatics, 27(14), 2021-2022.

[31] Glubb, D. M., Paugh, S. W., Van Schaik, R. H., \& Innocenti, F. (2013). A guide to the current web-based resources in pharmacogenomics. Pharmacogenomics: Methods and Protocols, 293-310.

[32] Herrgård, M. J., Swainston, N., Dobson, P., Dunn, W. B., Arga, K. Y., Arvas, M., \& Hucka, M. (2008). A consensus yeast metabolic network reconstruction obtained from a community approach to systems biology. Nature biotechnology, 26(10), 1155-1160.

[33] Choi, C., Münch, R., Leupold, S., Klein, J., Siegel, I., Thielen, B., \& Ebeling, C. (2007). SYSTOMONAS - an integrated database for systems biology analysis of Pseudomonas. Nucleic Acids Research, 35(suppl_1), D533-D537.

[34] Brown, A. J. (Ed.). (2006). Fungal Genomics (Vol. 13). Springer Science \& Business Media.

Citation: N. Khan, "System Biology-A Computational Platform for Biological Research", International Journal of Research Studies in Biosciences (IJRSB), vol. 6, no. 1, pp. 20-23, 2018. http://dx.doi.org/10.20431/ 2349-0365.0601005

Copyright: (C) 2018 Authors. This is an open-access article distributed under the terms of the Creative Commons Attribution License, which permits unrestricted use, distribution, and reproduction in any medium, provided the original author and source are credited. 